\title{
The Contingencies of State Formation in Eastern Inner Asia
}

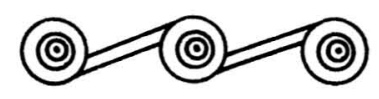

\section{J. DANIEL ROGERS}

\section{INTRODUCTION}

THE STEPPES, DESERTS, AND MOUNTAINS OF EASTERn INNER ASIA provide the backdrop for the rise and expansion of a complex series of states and empires. The polities that originated in the expansive territory encompassing northern China, Mongolia, and surrounding regions of Siberia and eastern Kazakhstan often played a central role in Asian and world history. In the analysis of the origins and development of these early states and empires, several long-standing points of articulation continue to define the differences between prominent theories of political and cultural changes in Inner Asia. This article identifies several key issues and evaluates the nature of existing evidence for each within the context of general theories of state and empire formation.

Recent research on the formation of early states and empires raises several critical issues relevant for eastern Inner Asia (Alcock et al. 2001; Baines and Yoffee 1998; Bondarenko and Korotayev 2000; Claessen and Oosten 1996; Richards and Van Buren 2000; Stein 1998). Although these studies concern diverse regions of the world, all place considerable emphasis on both the internal and external workings of societies to explain large-scale changes. At the same time, the contingencies of history are not treated as a mere chronicle of change but as an active agent connected to shifts in ideas, values, and social outcomes. The overall result is an approach that rests on an increasingly dynamic interplay of factors, some of which are dependent on the decisions made by individual actors and others by the convergence of particular historical trajectories, economic capabilities, and environmental constraints. In the various analyses, however, emphasis on particular factors often depends as much on specific intellectual traditions as on the availability of evidence.

Among studies concerned with early states and empires in eastern Inner Asia, three key themes repeatedly emerge. First, interaction with China in what is typically described as an insider/outsider relationship, with the Inner Asian polities assuming the peripheral role (cf. Di Cosmo 2002:2-3); second, continuity and discontinuity, or the causes for the apparently cyclical or short-lived existence of

J. Daniel Rogers is a curator and the chairman of the Department of Anthropology, National Museum of Natural History, Smithsonian Institution, Washington, DC. 
a succession of polities (cf. Lattimore 1940:529); and third, the internal organizational coherence of the steppe polities themselves. Each theme is fundamentally intertwined in the interpretation of Inner Asian history but also embodies issues common to the general study of state and empire formation.

To contextualize the argument presented here, it is necessary to mention some basic criteria for what constitutes both states and empires. There are many definitions for both of these terms (Johnson and Earle 1987:246; Sinopoli 2001:444, 447). In the past, debates surrounding issues of definition have often sidetracked analysis more directly related to problem-oriented interpretations. In this study, I use generalized definitions for both state and empire. A state is any political entity in which authority is relatively centralized and hierarchical, and one in which control extends over a prescribed population and territory. States have one or more population centers, often called towns or cities, and individuals living in a state recognize it as politically independent of other such entities. Empires are states developed through expansion to incorporate other states, polities, and regions, resulting in larger territories with increasingly diverse populations. These descriptions may be fuzzy at the margins; however, the focus here is on exploring social trajectories, not through definition of formal traits, but through analysis of the scope and novel combination of diverse sources of power and opportunity.

\section{THE INTERPRETATION OF INNER ASIAN POLITIES}

Diverse styles of scholarship have produced fundamentally different interpretations of the steppe polities. Particularly significant in traditional interpretations has been a Marxist perspective in which the pastoral nomads-considered the basis for all Inner Asian states - passed through distinct stages from primitive communism to patriarchal society, feudalism, and eventually socialism, with the rise of the modern state in the twentieth century (e.g., Potapov 1955:17). Other perspectives have been less explicitly Marxist but have routinely implicitly assumed stages of social evolutionary development. Other more restricted developmental models have focused on pastoralism, such as Pletneva's $(1982: 145)$ three phases of pastoralist mobilization: pure nomadism, seminomadism, and sedentism. Recent research offers several revisions to this argument, especially concerning the lack of evidence for European-style feudalism as applied to pastoralists of the era of the Mongol Empire (Bold 2001 :24; Gellner 1994 : xi; Kradin 2002).

Other significant approaches include models of cultural change over time derived from the documentary sources. These theories tend to emphasize a "historical causality" emerging from a unique series of events (Schortman and Urban $1992: 5)$. As in many other regions of the world, the history of eastern Inner Asian states is typically described as a relatively rapid and repeated replacement of political entities, most of which are known primarily from early documents. The sources tend to focus on the activities of the royal lineages, the conduct of war, and the expansion or contraction of polities, while many other issues are addressed in far less detail because they are simply considered unimportant to the overall interpretation.

The early documentary sources for Inner Asia certainly serve to mold interpretations, but they do not determine the potential for revision. Di Cosmo (1999:4), for instance, notes that some historians taking a comparative world history per- 
spective tend to assign particular roles to the steppe empires, namely as facilitators of interaction and trade between widely separated sedentary civilizations. In this way, the empires established by pastoralists served as catalysts-significant but only intermediary to more fundamental processes taking place elsewhere. Beyond this role they are relegated to a peripheral significance, as events occurring in the great centers of civilization in the Near East, China, and Europe received the greater share of attention (e.g., Chaliand 2004:xi). In this secondary role, the steppe empires are compared more in terms of their similarities than their differences and are treated as relatively homogeneous phenomena. Among the attributes often assigned to steppe polities is the "inability to spread indigenous cultural traditions and their adoption of, or assimilation by, the cultures they encountered in their conquests" (Di Cosmo 1999:4). Such an orientation essentially downplays the influence, potential, and even the organizational integrity of the steppe polities. Although, for instance, the Mongol expansion of the thirteenth and fourteenth centuries is viewed as a watershed in Asian history, analysis of the continuities and discontinuities of regional dynamics is still unfinished business.

Historians working in the region have pieced together detailed treatments of some early polities that can serve as the basis for interpretation of some of the key processes. In the case of the steppe polities, there are a number of named political entities, and although this study is concerned with the rise of states, the focus is primarily on the time after the emergence of the first major political consolidation. Given the complexities of Inner Asian history, the details of any such list is subject to debate. However, the purpose here is not to provide a definitive summary but instead to alert the reader to key names and approximate dates for the rise and decline of prominent polities described in more detail elsewhere in the literature (Barfield 1989, 2001:23; Idshinnorov et al. 2000; Jagchid and Symons 1989). For the study of early state formation and the emergence of empires, the sequence begins with the Xiongnu, which also had the expansionistic attributes of an empire (c. 200 B.C.-A.D. 155). The Xiongnu state is the first significant consolidation of nomadic pastoralists to which the already existing states in China were forced to react (Barfield 2001:23; Christian 1998:183; Watson 1961; Yamada 1982). Following the Xiongnu, the largest centralized polities in Mongolia, in chronological order, were the Xianbei (A.D. 155-235), Toba-Wei (A.D. 386-581), Jujan (A.D. 380-555), First Türk (A.D. 552-630), Second Türk (A.D. 683-744), Uighur (A.D. 745-840), Khitan (A.D. 907-1125), Mongol (A.D. 12061368), and Zunghar (A.D. 1625-1757). While some of these entities are known archaeologically from several sites, others are known almost entirely from written records.

\section{INTERACTIONS WITH CHINA}

The first theme-China's relationship to the steppe polities-is an issue of central concern and is part of the historical backdrop for consideration of the other themes. It is also an issue with general significance, considering that regional interaction is a routine factor in each instance of state formation. Extensive research leaves no question that states originating in China exerted powerful influences throughout much of Asia. This observation is not disputed, although significantly 
different interpretations exist over China's actual role in the reformulation of the steppe polities, especially following the rise of the Xiongnu state around 200 B.C. (Barfield 2001; Di Cosmo 2002; Jagchid and Symons 1989).

The central issue that guides most interpretations of China's interaction with the steppe peoples is the contention that the pastoral nomads needed the products of the settled societies to the south, especially agricultural products and a wide variety of high-value or luxury goods (Barfield 1989:8; Pritsak 1981:15-17). An enduring impression has emerged that China, by contrast, had little interest in the products of the steppe regions, as evidenced by its long history of building walls between the two regions (Lattimore 1976:481). The reasons for building walls may have been defensive, but a rejection of economic exchange should not be assumed. Although the simplistic duality is not borne out in recent research, an economic and environmental contrast still forms the foundations of most interpretive models of China-steppe interactions. The perceived instability of steppe environments, in particular, and the consequently narrow economic base of the nomads are cited as the reasons for lack of economic and cultural parity (Krader 1978:104). This is the well-known dichotomy of the "steppe and the sown" that has guided interpretations for decades. In either traditional historiography or in culture developmental models, interpretations are heavily influenced by this dichotomy. In the case of Inner Asia, the distinction is implied in writings going back as far as the Zhou dynasty (1050-256 B.C.), in which Chinese authors speak of peoples to the north in less than flattering ways (Li 1973, vol. 1:209). This often-repeated Chinese view of northern peoples became an enduring stereotype, with ongoing significance in current interpretations (Di Cosmo 1994:1092). Dichotomies like this find parallels in a wide range of anthropological literature on the subject in which pastoralists are viewed as marginal peoples that occupy unstable environmental zones (Weissleder 1978).

In some aspects, however, the dichotomy between the steppe and southern regions is legitimate, considering that for more than 2000 years China and the peoples of the steppe interacted in various ways, yet neither incorporated the other linguistically, culturally, economically, or politically (Barfield 1989:2). Even when a Mongol lord sat on the throne of China, aside from an elite veneer of cultural conformity adopted by the conquerors, distinctive ways of life and language continued along very different lines. Although culture contact between China and the northern steppe regions was routine, there was and is a distinctive cultural divide.

The consequences of culture contact are socially negotiated and mutually determined processes that vary with time and place. In the long history of interaction between China and the steppe polities, the range of factors that come into play at different times is wide. While the dichotomy may be in common usage, it often fails as an interpretive tool when applied generically because neither China nor the steppe polities are uniform in their organization or social motivations, either geographically or at different points in time. Likewise, the economic criteria for the dichotomy cannot be rigidly divided. Although it is often assumed that China's agricultural products were necessary to sustain the steppe polities, the steppe regions were not engaged exclusively in herding; they also practiced some level of complementary agriculture (Dawson 1955:100; Honeychurch and Amartuvshin 2002; Minorsky 1947; Rogers et al. 2005). In southeastern Kazakhstan, 
Rosen et al. (2000) have identified a process of agricultural intensification associated with the Saka (c. 750-300 в.C.) and the Wusun (c. 300 B.C.-A.D. 200) periods. From the Transbaikal region, Kradin's (2005) analysis of potential agricultural productivity at the Ivolga site shows that settled agriculturalists (2500 to 3000 people) could have supplied a significant amount of grain and vegetables within a major portion of the Xiongnu Empire.

The second aspect of the presumed necessary relationships of steppe communities with China involved access to luxury goods. The term "luxury goods" is used here in a very generic sense to mean a wide range of raw materials and products that were not available locally but were deemed to be of high value either socially, symbolically, or economically. Such goods were certainly important to the steppe polities; however, China was only one of several sources. For instance, long before the Chinese "officially" opened the Silk Road in 130 B.C., interaction with a variety of Bronze Age and earlier groups was common throughout Central Asia and Siberia (Askarov et al. 1999:463; Chang et al. 2002:158). The principal "cultures" of the Bronze Age in Central Asia-defined on the basis of temporal and spatial variation in artifact assemblages-consist of several regional expressions, including the Fedorovo/Karasuk, Alakul, Sintashta/Petrovka, Nurinsky/ Atasu/Begazy/Dandybaevsky, and the Semirech'ya. Although there is increasing evidence for diversity, these groups are often still referred to collectively as the Andronovo Culture or Cultural Community. The new evidence has allowed a reinterpretation that notes connections but recognizes the presence of considerable diversity (Frachetti 2004:201, 203). The nature of this diversity is outlined in several articles in two recent volumes (Boyle et al. 2002; Jones-Bley and Zdanovich 2002). The nature of interaction among these groups and among cultural complexes in Mongolia and China was most likely not through a formal trade network, like the Silk Road, but was through extensive and highly variable connections ( $\mathrm{Li} 2002$ ).

Direct evidence for the nature of exchange relations over this vast region can be explored through the production, style, and actual trade of bronze and coppery alloy objects (Linduff 2004). For instance, it is widely recognized that bronze metallurgy was introduced into China through Western connections (Chiou-Peng 1998; Peng 1998). A Western source of this technology and raw materials comes from a region referred to as the Circumpontic Metallurgical Province and includes mines in the Ural and Carpathian mountains. Here, mining technology was developed by at least the third millennium B.C., later spreading throughout Central Asia (Chernykh 1992, 1997; Chernykh et al. 2002; Frachetti 2002:165-166). In the eastern steppe, copper and tin sources in the Altai Mountains and Minusinsk Basin provided the raw material for widespread production and exchange by the early part of second millennium B.C. Throughout these regions, there is substantial evidence in chemical sourcing of metals and stylistic connections to document long-distance exchange and local production in these highly valued goods.

By the late Bronze Age, numerous sites in the Tarim Basin, Xinjiang, and other parts of northern and western China provide archaeological evidence for even more interaction (Kuzmina 1998; Mei and Shell 2002). Later Chinese documentary sources also make it clear that the Xiongnu polity conducted wars and derived tribute from the distant city-states of Turkestan (Hulsewé 1979: 
216-217). The mobility afforded by horse, camel, and other pack animals facilitated Inner Asian trade in west to east directions, but also with southern Siberia. The evidence for these cultural contacts and trade in luxury goods, as well as more mundane items, is extensive in archaeological sites throughout the region from the Bronze Age on (e.g., Boyle et al. 2002; Jones-Bley and Zdanovich 2002).

In general, the need or desire for the types of goods acquired from China relates to processes associated with the existence and structure of steppe elite social strata more than with the nature of the steppe economy. Differentials of social status recognizable in several regions of the steppe during the Bronze Age are the basis for the later development of elite lineages. As was certainly the case in the Bronze Age, wealth was an active agent of social differentiation in early states that produced royal lineages and allowed them to maintain control. However, the presence of such items in a neighboring society alone is insufficient to generate the need to acquire them through force and the extensive social changes associated with state formation. It is far more likely that the emergence of recognized elite lineages in the Bronze Age began a process of creating and utilizing wealth from many sources to sustain and expand internally recognized objectives as part of a prestige-goods economy. Even prior to the formation of states, foreign (exotic) goods were arguably emblematic of power, privilege, and forms of knowledge held by chiefs and other elite practitioners in society (Helms 1988). From studies of culture contact, however, the cultural significance of trade goods is highly subjective, and value is not necessarily the same across major cultural boundaries. Even so, the lessons of the Silk Road demonstrate that the desirability of some goods was interchangeable across great distances (e.g., Allsen 1997). Foreign luxury goods may have been especially significant for the steppe polities that formed as confederations or hierarchical alliances of relatively independent groups. In this type of organization, maintenance of the confederation often depended on the ability of central elites to provide subordinates with access to luxury goods as part of the maintenance of alliances.

In some regards, the emphasis usually placed on China as the source of goods and ideas for the steppe polities also derives from the fact that complex polities formed there first. Exactly what constitutes evidence for the emergence of early states as a form of social and political organization is highly debatable; however, there is extensive evidence from China for complex social hierarchies, craft specialization, and urban centers at an early date (Lee 2002). The Xia polity (c. 2100-1700 B.C.), which existed within the Longshan and Erlitou Cultures, is often cited as the first state in China (Chang 1986:305-307; Liu 1996:242; Shen $2003: 290)$. In Central Asia, the Scythian state came into existence by the seventh century B.C. (Khazanov 1981), but in the steppe regions bordering China the first recognized centralized polity is the Xiongnu, which did not emerge until around 200 B.C. according to historical sources. The disparity in timing alone calls into question any processual linkage between the two regions. Still, many details available from written sources have made it possible to posit direct cause and effect relationships, such as Barfield's (2001:10) characterization of the steppe polities as "shadow empires" that emerged or declined in response to alternating periods of centralization and political anarchy in China. Others argue that the rise of the Xiongnu was connected to a political and military response to Chinese incursions and not directly to the unification of China (Di Cosmo 2002:187-188). 
Although states took shape earlier in China, the Xiongnu did not hold a subordinate political, economic, or military status other than in Chinese perceptions of northern peoples. In fact, there is considerable evidence that - at least militarilythe Chinese adopted several technologies and strategies from the Xiongnu. Included among these were the ideas of leather body armor and a regular cavalry utilizing large numbers of horses (Chavannes 1913:xv-xvi). Likewise, through the ho-ch'in treaty policy of 199 B.C., the Chinese adopted a strategy of appeasement, while also beginning an attempt to indoctrinate the Xiongnu by sending rhetoricians to expound Chinese rules of conduct (Ying-shih Yü 1967:10-12). These forms of interaction imply some degree of parity between the Xiongnu and Chinese states. From later times, there are many other examples of how the steppe elites utilized expertise from China and other sources. For instance, the Uigher polity relied on Sogdian advisors from the west (Mackerras 1972:10). In the Second Türk state, the Chinese-educated chief minister Tonyugug is credited as the architect of the strategies that allowed the Türks to consolidate control (de Rachewiltz 1970:59). In the early stage of the Mongol Empire, Chinggis Khan's court was heavily assisted by Uighurs employed as scribes and officials (Allsen 1997:6). Although China's long history of statecraft, scholarship, dense populations, intensive agriculture, and stable sources of wealth might naturally be considered the source for all other regional states, the interactions turn out to be far more dynamic and far more selective than commonly acknowledged.

In most cases of state formation throughout the world, there are issues of proximity and influence from already existing states paralleling those experienced in Inner Asia. The extent and nature of China's participation in social and political developments in Inner Asia is extremely complex and highly variable. Although China-along with Mesopotamia, Mexico, and Andean South America-is widely regarded as a region where the first states developed, it is always necessary to evaluate the nature of interactions with surrounding regions. Even in the first few states, changes in social complexity invariably had regional variations (Bender 1990:247; Price 1978; Wright 1977). In East Asia, the different Chinese states eventually came to exert considerable influence on surrounding regions such as Viet Nam, Korea, and Japan. However, the steppe regions to the north were remarkably immune to Chinese language, writing systems, calendrics, political systems, ideologies, and other aspects of culture. Arguably, the major basis for this north-south cultural divide was the great difference in the environments, coupled with the development of distinctive cultural practices over a period of more than 3000 years.

Although the interactions between China and the steppe polities did not result in a syncretism of cultures, the details of the exchanges and interactions provide important clues in the appearance of several of the steppe polities. Likewise, interactions with China were often on a level of parity or even control by the steppe polities. Certainly some technologies from China came north to the steppe regions, but what remains to be explored is a north to south trajectory of cultural influences (Barfield 1989:140).

\section{CONTINUITY AND DISCONTINUITY}

The second theme concerns the role of continuity and discontinuity in cultural practices among the several polities dominating the region beginning with the rise 
of the Xiongnu Empire. Rather than only origins, change, and collapse, it is also useful to consider the mechanisms of continuity in the formation of states and empires. Even considering the presence of ethnic and linguistic diversity, there are continuities that operated within a given region. One effect of continuity is that successor polities are increasingly constrained, but not determined, by particular histories. Through this mechanism, continuity and breaks in continuity tend to become increasingly important explanatory tools when charting regional dynamics. The concepts of continuity - and the alternative of discontinuity - in social, economic, or political arenas provide insights into how early states and empires emerged and transitioned into differing forms of organization. Even with the emergence of new organizational patterns, differing regional histories exhibit enduring cultural constructs that retain meaning over long stretches of time; often these are referred to as civilizations (Baines and Yoffee 1998:235; Van Buren and Richards 2000:5; Yoffee 2005:15-19). Continuity essentially concerns the creation of sets of ideas with value that operate across time at a scale beyond those typically associated with the rise and decline of an individual polity. For eastern Inner Asia, the idea of continuity finds resonance in Di Cosmo's recent discussion of "traditionary" materials that operated as "a set of diffuse political conventions, quite separate from the 'traditional' customs and rituals that may demarcate the ethnic boundaries of a given clan or tribe" (1999:7). The idea of "traditionary" supports a broader consideration of continuities through recognition of a cultural-historical tie linking political institutions within a particular region.

Commonalities of political institutions, social organization, and cultural practices operate across ethnic, religious, linguistic, or other cultural boundaries in time and space. In southern Siberia and northern Mongolia, there is no shortage of archaeological evidence for the emergence of social hierarchies that could have served as prototypical forms for later states. The Afanesevo cultural complex from the third millennium B.C. includes substantial settlements with domesticated animals and may be a cultural source for some of the Bronze Age constructions in Mongolia (Kuzmina 2001). The stone Bronze Age monuments of Mongolia include slab burials, mounds called khirigsuurs, and the monolithic deer stones (Fitzhugh et al. 2005). These stone monuments are part of an elaborate cultural landscape that included aspects of public ritual and the likely connection with clan and elite lineages (Allard and Erdenebaatar 2005). From southern Siberia, a uniquely elaborate kurgan-Arzhan 1, dated to the ninth century B.C.- provides a striking example of further evidence for well-established social hierarchies on the eastern Inner Asian steppe well before the emergence of the Xiongnu state (Askarov et al. 1999).

The contingencies provided by history coupled with the selective use of memory form part of individual and shared identity, serving as a storehouse of possibilities and limitations. Long before the emergence of the first state, there is evidence for individuals in positions of leadership organized hierarchically employing aspects of history through symbolic continuities to either solidify or refute claims to authority. These usages derive from the implications of tradition, including retelling of significant mythical events, genealogical relationships with founding ancestors, association with particular regions, and other sources for claims of position and privilege. In this regard, it may be valuable to look at the "formative" in the processes of state formation as more than a point of origin, and 
instead consider it as a source of constraints and ultimately systems of value that formed the social continuity, discontinuity, and disjunctures integral to the formation of states and empires (Joyce 2000:67). This is particularly significant when state formation is conceived as a process of intensification of existing needs, conditions, and objectives. Essentially, the creation of states allows individualsespecially those in positions of influence-to realize personal motivations. These motivations may be viewed as altruistic or selfish, but they are usually based on cultural practices derived from a variety of sources, many with long traditions. In this way, the actions of individuals become contexts of innovation within prescribed ranges of possibility.

Much of the writing of state and empire history for Inner Asia emphasizes the sequential uniqueness and lack of continuity between political and social entities. The progression of named polities, mentioned earlier, implies an interpretation based on the succession of elite lineages as tied to major conflicts and the resulting emergence of a new political order. In this way, the causes of change emerge as external to the workings of a particular polity. Such external factors as invasion, or another form of crisis, then emerge as likely causal agents in the disjunctures between polities. However, the issue here is not the specific causes cited for the collapse of one political order and its replacement by another but instead the variability inherent in the transition itself and the implications for analyzing sources of power and their reformulations (cf. Cioffi-Revilla 2005). For instance, in the reported fall of the northern segment of the Xiongnu Empire in A.D. 89, large portions of its diverse population were incorporated into the succeeding Xianbei polity (Barfield 1989:80; Ishjamts 1994:155-156) and others fled the region, while many subgroups joined the southern Xiongnu, who had already allied with the T'ang dynasty in China (Parker 1894-1895:259). By contrast, documentary sources report that the fall of the Uighur state involved destruction of its huge capitol, Khar Balgas, and displacement of its population, especially far to the west (Mackerras 1972:124-125; Minorsky 1947:278). To what extent are these divergent outcomes a result of specific events versus a trajectory of change?

Chinese historians writing at the time, or in some cases decades after an event, typically were the first to record the information used to construct the above culture history sequence. What appears to be the relatively rapid and repeated replacement of political entities specifically raises a series of questions about continuity, discontinuity, the role of internal organization, and external interactions. Such sequences specifically de-emphasize continuity while emphasizing discontinuities in cultural and political organization. Some of the discontinuities represented in the documentary sources may actually have involved a range of outcomes far less final than the collapse of a state (Bronson 1988:197). In those areas of the world with long written histories, the time units that make up a sequence typically revolve around dynastic successions or other events in military or political history. The Egyptian dynasties between the Predynastic period and the Roman period are well-known examples of successional chronology derived principally from written sources (Richards and Wilfong 1995). In contrast to Egypt or Inner Asia, regions with few or recent documents, history becomes a succession of "cultures." This is the typical distinction between prehistory and history, and the definition of what is noteworthy in a region often rests on the availability of written documents in opposition to other forms of information. It 
is also significantly dependent, however, on the theoretical orientation and the disciplinary style of particular investigators.

The counterpoint to the sequence of named polities and their implied political and social disjunctures is the evidence for significant forms of continuity across these same apparent boundaries. Certainly, the most obvious derive from a basic steppe economy emphasizing a form of pastoralism that emerged in the Bronze Age by at least 1500 B.C. in Mongolia (Allard and Erdenebaatar 2005; Bold 2001), in combination with varying levels of agriculture (Chang et al. 2002:151; Di Cosmo 1994; Honeychurch and Amartuvshin 2002; Ishjamts 1994:158; Vainshtein $1980: 164)$. In order to stress the mechanisms of state formation, aside from these fundamental economic similarities, states emphasized many of the same attributes that foster continuity across significant stretches of time. Alternatively, statecraft as a process does not necessarily imply continuity of economy or cultural practice, since there is no inherent reason these characteristics might lead to development of increasingly complex social systems. A very important factor that does tie together the regional approach to state formation is continuity within the ideological patterns used by elites to establish and legitimate control, otherwise termed social power.

The emergent forms of social power in early states produced a political economy of authority, typically materialized through the creation of monuments, central places, use of public symbols, ritual, language, and other ways of developing culturally mediated landscapes (e.g., DeMarrais et al. 1996). Of course, social power can be achieved by other means. Obviously, coercion and conquest establish control over groups and regions. The use of force, however effective in the short run, is a costly and unstable way to perpetuate control. Establishing and maintaining social power eventually depends on strategies for legitimating authority, both in the process of initially consolidating groups into a single confederation - as was typical among the steppe polities - and later in the expansion of those states to include new populations and territories. In raising the issue of continuity, the critical question for archaeologists becomes whether in periods of transition or collapse, symbols and other forms of materialization continue to communicate similar meanings or whether they undergo a process of reinterpretation. The historical record provides examples of the application of coercive force and legitimation of control and how these processes were materialized in successive polities.

As in early states around the world, there is substantial evidence for the use of heavenly mandates to justify authority (Kürsat-Ahlers 1996:139-141; Trigger 2003:87). Throughout the history of eastern Inner Asia, there are significant commonalities of ideology and legitimation of control. In the Xiongnu state, the earliest references to the king (shan- $y \ddot{u}$ ) already imply divine sanctification through the use of titles such as Great Son of Heaven (T'ang-li-ku't'u Shan-yü) (Christian 1998:195; Ishjamts 1994:158). Titles such as this are similar to Chinese royal titles and are usually considered evidence of Chinese influence. However, the concept of gods of heaven (tengri) is widespread in eastern Inner Asia and is especially well known from later Türkic and Mongol religions (Heissig 1980), where they are commonly cited as a foundation for authority to rule. Given these potential sources for ideas about divine leadership, it is premature to consider China as 
the only possible source (Allsen 1996:117). Furthermore, versions of titles as rendered by Chinese historians may represent their interpretations according to conventions of the time. In fact, Kürsat-Ahlers $(1994: 266)$ argues that the first part of the Xiongnu king's title actually derives from the word "tengri," thus referencing the traditional beliefs of the steppes rather than China. Likewise, on comparative grounds, there is no need to credit China as the only source of ideas since new ideologies of authority are frequently created at the time of leadership centralization and do not have to be borrowed from neighboring sources (Flannery 1999: 15-17; Sahlins 1981).

Inscriptions of Türk and Uighur origin dating between A.D. 552 and 840 confirm three components to the legitimation of authority. As described by Allsen (1996:116), these include (1) the continuation of the heavenly mandate of the sky-god Tengri as seen in the Xiongnu Empire; (2) the application of this authority to control of the entire steppe, if not the entire world; and (3) special good fortune bestowed to the particular leader (Golden 1982; Khazanov 1993:465466; Mackerras 1972:64-65, 80-81). The special relationship of leaders to divine power parallels those used by shamanic traditions to attain spiritual leadership and is apparent in early texts relating to the origin of the Türk states (Eliade 1964:189; Golden 1982:42), the Khitan polity (de Rachewiltz 1970:59), and the Mongol Empire (Cleaves 1982:176-177).

The legitimation of authority also had a materiality expressed in a sacred geography relating to ethnic origins and mythic ancestors. Although discussed by many authors, Allsen (1996), Golden (1982), and Kürsat-Ahlers (1996) in particular describe the use of sacred places as sources of legitimation and continuity linking the steppe polities. Among the several significant locales, the Orkhon River Valley in central Mongolia stands out as a key region.

In a tradition that may have gone back as far as the Xiongnu, the Orkhon Valley region was an area of imperial camps, sacred places, and cities. Although not based on direct archaeological evidence, the Xiongnu capital of Lung-Ch'ìen is thought to have been located in the southeastern portion of the Khangai Mountains near the Orkhon Valley (Allsen 1996:124; Ishjamts 1994:156). In the same area, documentary sources note that the Jujan and Türk states had holy places associated with the authority of the rulers. The Türks called the region Ötükän yii and acknowledged it as a central place necessary to the governance of the polity (Allsen 1996:124; Golden 1982:49). Later documents relating to the Uighur state (A.D. 745-840) are even more explicit, with eyewitness descriptions of the city and palace at Ordu Baliq (Khar Balgas) in the Orkhon Valley (Minorsky 1947). Uighur origin myths provide the deep connections with the region, with both Persian and Chinese sources linking Uighur origins to Kharkhorum or Quorum (Ho-lin) mountain at the edge of the Orkhon Valley (Juwayni 1912-1937, vol. 1:39-46, 191-192; 1958:54-61, 236; Su T'ien-chüeh 1967, ch. 26:1b2a). The later Khitans (A.D. 907-1125) acknowledged the spiritual significance of the Orkhon region but were not themselves of the region and maintained their political centers in southern Manchuria and northern China (Allsen 1996:125). Although remaining significant to various Mongol groups, it was not until the rise of the Mongol state under Chinggis Khan at the beginning of the thirteenth century A.D. that the Orkhon region again assumed a major political role. The 


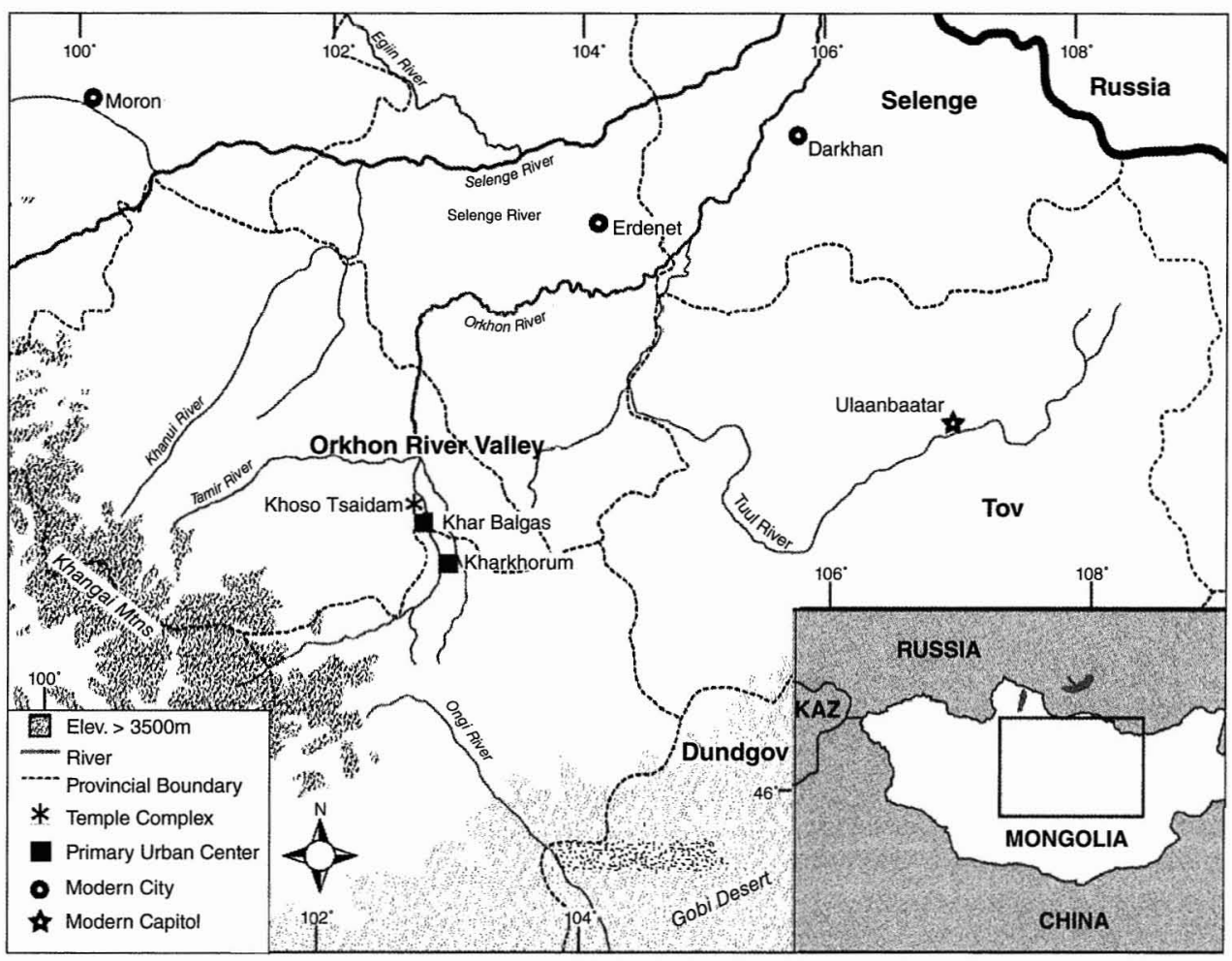

Fig. 1. Central Mongolia showing the Orkhon River Valley and key archaeological sites mentioned in the text.

Mongols were undoubtedly aware of the traditional significance of the region when they established their central place at Kharkhorum, $24 \mathrm{~km}$ south of the former Uighur capital and only $16 \mathrm{~km}$ from the Türk temple complex at Khosho Tsaidam. Even so, the decision to build at Kharkhorum was not made hastily. Juwayni (1912-1937, vol. 1:39-46, 191-192; 1958:54-61, 236) reports on an early use of archaeological techniques by the Mongols. At Ordu Baliq they excavated a stele and brought in scholars to translate the Chinese script. The translation confirmed that the Uighur khan Bögü had lived there, thus providing the Mongols a further link with ancient royal traditions.

Mongol exploration of ancient traditions and the use of those findings to bolster a sense of continuity speaks to the process of legitimating authority through the constraints and opportunities that emerge from the acquisition of specialized knowledge. Coupled with the new information was the explicit invention of tradition. The Mongols were not ethnically close to the Uighurs, but there was value in fostering a tradition of continuity that linked the right to rule with the region. Besides the Mongols' purposeful efforts to build continuity, other significant linkages derived from the traditions of the Türk states and a broad tradition of steppe religious practices that often existed in parallel with more newly arrived belief systems, including Buddhism, Islam, Judaism, Manichaenism, and Nestorian Christianity. 


\section{CONSTRUCTING ORDER}

The third theme-organizational coherence-broadly concerns patterns that exist in the construction and maintenance of order. In particular, the objective in this section is to consider how the previously discussed issues facilitate the creation and maintenance of operating strategies appropriate to particular historical circumstances associated with the emergence of the first state and successor states. In eastern Inner Asia, the patterns that form the basis for organizational coherence and a particular trajectory of change can be traced at least to the emergence of Bronze Age pastoralism in the second millennium B.C. (Honeychurch and Amartuvshin 2006:259). Even within a framework based on animal husbandry, regionally diverse societies throughout Central Asia adapted differing subsistence systems to local conditions. This economic and social diversity provided a rich source of potential for the formation of basic social hierarchies.

The construction of order occurs within the context of power legitimation and the implications for maintaining political and organizational control of populations and territories. In fact, order depends on a significant portion of the population accepting the claims to legitimacy used by the ruling elite. It therefore embodies an ideology that incorporates the mechanisms of control, the ruler and his or her instruments of control, along with belief systems (Baines and Yoffee $2000: 14-15)$. It is fundamental for any organization to establish and institutionalize those methods of legitimation. In the Inner Asian case the existence of forms of order is not in question, but the sources of the cultural knowledge that allowed order to materialize in differing forms is a contested subject area, particularly as it concerns the role of sedentary states. Although China is often viewed as the ultimate source, there is evidence that the forms of cultural knowledge that allowed maintenance of order were derived from many sources, and they came especially from the long traditions that linked successive steppe polities.

Even with the existence of traditions and ideologies of control, there was still the process of converting these into a coherent state organization-the construction of state order. For the steppe polities, as in virtually all early states, constructing order revolved around the centralization of control, including the conversion of kinship-based authority to office-based authority; the control of key resources; the geographical positioning of administrative functions; and the bridging of ethnic and linguistic diversity. These and other aspects of control are widely articulated in discussions of state formation (e.g., Hunt and Hunt 1978:78-79), including heterarchy and other alternatives to the emphasis on elite centralization (Blanton 1998:138-139; Ehrenreich et al. 1995).

The centralization of control was essentially the result of the establishment of an elite hierarchy capable of bringing independent or loosely affiliated groups together for a common purpose (Spencer 1994). In some cases the groups shared cultural bonds of language and ethnicity and sometimes not. Given the contexts of Inner Asian environment and resources, the mechanisms involved in making the leap to a multigroup organization usually entailed a combination of charismatic leadership, control, and at least fictive redistribution of resources, control of information, and coercive force. Here the issue of organizational coherence comes into play more in the transitioning from one recognized polity to the next than in the first major consolidation of power under the Xiongnu. Since ascribed 
and hereditary leadership was widely recognized - almost certainly before the existence of the first states - those leaders in a position to affect change by bringing together diverse groupings were also in a position to centralize authority by modifying existing traditions of leadership. This could be accomplished without having to invent a new ideology of control (cf. Sahlins 1981). Although Di Cosmo (2002:184) argues that the establishment of a "semi-vertical" authority structure was the equivalent of a social revolution, the existence of hereditary leadership and long traditions of fluctuating political subordination points to a less radical process of adjustment as is typically initiated in early state formations (Flannery 1999: 15).

In most instances, authority emerged through the establishment of a confederation and systemic power, as opposed to interpersonal power derived from kin relationships (Lehman 1969:455-456). Numerous confederations were short lived; only rarely were the conditions right for the continuation and expansion of a polity with centralized control. Often charismatic leadership played a role, but a critical step in the growth of the polity was the transitioning from hierarchies based exclusively on kinship relationships to those incorporating at least a mix of kin-based positions with categories of office (Di Cosmo 1999:21; Gailey 1985). This phenomenon can be seen in several polities, including the Xiongnu, Uighur, and First Türk (e.g., Mackerras 1972:190-194), while others, such as the Mongols, dismantled existing structures and imposed positions of office filled by capable individuals loyal to the khan but usually not kin (Barfield 1989:192, 197). Even with a transition to categories of office, the death of a khan often meant the demise of the polity, considering that rules of succession did not prevent royal infighting and civil war (cf. Sinopoli 2001 : 452).

While all of the steppe polities did emerge with some form of centralization of authority, there was also a corporate political aspect. Even in instances of effective centralized leadership, subordinate leaders-especially those holding established positions in local group hierarchies - continued to play important roles. The ideology of power and the allegiances attested to in the confederation of relatively independent groups almost guaranteed that individuals would continue to compete for position and resources. The motivations of these individuals were often counter to the goals of the centralized leadership. For those steppe polities with adequate documentation, the corporate solution to divergent interests becomes apparent in the existence of ruling councils that had to be consulted and other limitations to royal authority (e.g., Barfield 1989:209; Parker 1900-1901:2). In subsequent empires, it should also be noted that although a core of authority existed, administration also relied on a decentralized indigenous bureaucracy that often functioned in relatively autonomous ways.

As with the centralization of a core of authority, the control of key resources was critical to both the emergence and stability of the steppe polities. These resources included the ability of the leadership to provide access to the fundamentals of water, grazing lands, and agricultural crops, as well as trade in a variety of goods. The latter was particularly important in a redistributive sense as symbolic capital, if royal clans were to maintain the allegiance of subordinates. Trade, or the coercive alternatives of raiding and warfare, provided access to exotic products that served a fundamental role in a prestige goods system intended to continually reaffirm and solidify authority (Bourdieu 1977:179-180; D'Altroy and 
Earle 1985; Friedman and Rowlands 1977). As discussed above, for eastern Inner Asia the parameters of exchange typically hinge on defining the steppe polities as economic dependents of the Chinese states. There is no question that the acquisition of prestige goods from China was critically important; however, emerging evidence points to a far more dynamic range of interactions contributing to the wealth of the steppe polities.

The construction of ideologies of authority and the control of resources are part of the amassing of political capital by central elites as they attempt to bind together ethnically and linguistically diverse populations. Although the succession of steppe polities implies the replacement of one ethnic group by another, the evidence for continuity is reference to a far different situation-one in which populations frequently relocated or were incorporated by successor states. Some brief comments in early Chinese sources about the fall of the Xiongnu and the rise of the Xianbei polity make the point very well. In this instance, it was reported that 100,000 Xiongnu families were incorporated in the new polity and adopted the Xianbei ethnic name (Ishjamts 1994:155-156). The number of 100,000 may be unrealistically high; however, the point is that the incorporation of diversity did occur within the new polity. Other examples are frequently mentioned, as polities expanded their territories or incorporated defectors from rivals (e.g., Golden 1992:2).

The bridging of ethnic and linguistic diversity in the construction of order by elites is important because such diversity is a source of a variety of competing ideologies that can be potentially disruptive to power relations. This does not mean that early states necessarily tried to homogenize populations, but it does mean that workable tactics had to be used. The typical approaches can be grouped into four strategies. The first is elimination of diversity and involves attempts by the centralizing hierarchy to decimate the population or in other ways coerce conformity among incorporated groups. This strategy is often associated with conquests motivated by strong ideational perspectives, which was relatively uncommon in East Asia (e.g., Bronson 2000:124) but widespread in many other regions. The elimination of diversity may involve such approaches as dismantling indigenous leadership hierarchies, the co-opting of significant cultural symbols, the expulsion of particular groups, or genocide. In the Mongol and other empires, expansion often included the wholesale slaughter of populations that refused to surrender (Dawson 1955 : xiii), although this had more to do with insuring submission than it did with limiting diversity. Among the 19 steppe polities discussed here, none systematically attempted to eliminate diversity.

A second approach is creation of continuity and is a deliberate strategy of finding organizational and cultural linkages to form bonds across the range of variation. This approach is associated with elite strategies for legitimation, but it is directed at solidifying control of diverse populations and may include public symbolism for audiences beyond the elite. The Xianbei incorporation of Xiongnu families cited above may be an example of the deliberate creation of forms of cultural continuity through the denial of diversity and the creation of tradition. Other possible aspects of this approach include the creation of state religions (e.g., Blanton et al. $1996: 11)$ and the more typical and less drastic formal exchange of gifts and marriage partners between centralized leaders and the elite families of subgroups and newly conquered regions. These exchanges were almost ubiquitous in the forma- 
tion of alliances, treaty negotiations, and consolidation of subgroup linkages (e.g., Cleaves 1982:185).

A third strategy is overlay mechanisms - approaches that subsume diversity by importing administrative structures that bypass existing systems of political and cultural organization. Under this strategy, diversity is largely bypassed and the populace is viewed as interchangeable pieces of the larger whole. This does not mean that diversity goes unnoticed-only that important points of organizational articulation are removed from the preexisting culturally based realms. Overlay mechanisms may actually allow religious and other forms of diversity to thrive as long as major conflicts do not arise. An example is the wide range of religions represented in the Mongol capital at Kharkhorum, as reported by William of Rubruck in 1254 (Dawson 1955:184; Khazanov 1994). While this is a simple approach, it is also risky for an emerging empire in that it does not provide longterm solutions to the problem of creating unity from diversity.

A fourth approach is marginal incorporation, a strategy often seen at the frontier of expanding empires or in situations in which colonization or other forms of direct usage do not apply to a newly incorporated region. Marginal incorporation usually involves pledges of submission by the indigenous leaders and the payment of tribute and is the principal strategy of hegemonic empires. Preexisting elite hierarchies remain in place, except perhaps at the highest levels, and the expanding empire does little to interfere with internal management. Sinopoli $(2001: 444)$ argues that marginal incorporation is actually the norm for most early empires and is one of the major contributors to the fragility of these organizations. The steppe polities were certainly less than stable while employing a strategy of marginal incorporation at some point in their efforts at consolidation and expansion. The confederacies of the Xiongnu, Türks, and Khitan all provide good examples of this strategy. Some of the most detailed information is available from sources concerning the Mongol expansion, such as tributes of gold, silver, pearls, and textiles extracted from the Uighurs of Turfan and the Tangut state of Kansu (Cleaves 1982:172, sec. 238 and 186, sec. 249; Terent'ev-Katanskii 1993:13, 19). Here again, diversity issues implied by incorporation of a new region are bypassed.

Each of these four strategies represents an ideal type of interaction applied sequentially or selectively in different regions as part of the expansion of a particular state. In fact, expanding states did selectively employ these strategies in different regions, depending on economic conditions and the extent of ethnic differences. Logistical techniques, such as establishment of different types of colonies, routinely occurred in any of the first three strategies (Rogers 2005). A second observation about these strategies is that people subsumed within an expanding empire almost certainly engaged in forms of overt and covert resistance. The early documents talk about rebellion, but the anthropology of colonialism has amply demonstrated many other ways in which people resist the circumstances of control (Dirks 1992; Miller et al. 1989). In the co-opting of cultural symbols, the creation of tradition, or other efforts to legitimize control, for instance, there is no reason to assume that individuals were easily convinced of a rewritten history or newly formed genealogical relationships to the ancestors. That people do so is an assertion of statecraft, which inadvertently forms the basis 
for the emergence of organized opposition. In the end, the success of the state then depends on the extent to which populations become active participants in the newly defined order.

\section{CONCLUSIONS}

States take shape in multiple ways and for multiple reasons (Adams 1988:37; Cohen 1978:8). Although there are many potential causal factors for state formation and collapse, there is rarely if ever a single cause not contingent on the interplay of a range of other factors (e.g., Alcock et al. 2001; Feinman and Marcus 1998; Yoffee and Cowgill 1988). For the steppe polities of eastern Inner Asia, most interpretations of state and subsequent empire formation are associated with the opportunities and conflicts arising from interaction with sedentary statesparticularly China (Barfield 1989, 2001). The fragility of the steppe pastoralist economy has been viewed as the basis for the eventual need to acquire agricultural products, resulting in a dependence on sedentary populations (Krader 1978). New information and reinterpretations have successfully challenged the old pastoralist versus agriculturalist distinction (Cribb 1991:24-25; Di Cosmo 1994; Rogers et al. 2005), although it remains a common perspective. Studies that emphasize this economic dichotomy argue that nomadic pastoralists develop political hierarchies only because of interaction with neighboring state societies (Irons 1979:362; Khazanov $2001: 1$ ). Given this interpretive orientation, the role of influences external to the Inner Asian polities remains a dominant explanatory factor, while also being evident in interpretations that favor a cyclical explanation to account for the sequence of steppe polities (Barfield 2001). There is reason to suggest that such external interactions are always significant but do not account for the actual forms or trajectory of social organization observed in several instances. The evidence cited in the above sections points to a far more dynamic process in which an intensification of the needs, conditions, and objectives of elites created circumstances that brought other causal factors into play.

The literature provides many examples of how leaders asserted the right to rule. In each instance, continuities with past cultural practices were emphasized, even if it meant manufacturing those traditions. Likewise, the existence of an underlying set of religious beliefs associated with forms of Altaic shamanism that included the supreme sky god Tengri, the earth goddess Etügen, and other gods played a role in continuity and legitimation of authority. Steppe leaders using heavenly mandates to justify power is not evidence for the adoption of Chinese imperial ideologies, as suggested by Golden (1982:48) or de Rachewiltz $(1970: 59)$. Beyond the continuities in cultural practice, there were interactions that extended in every direction, thus removing the need to look only to China for models of royal legitimation. Other models for cosmologically sanctioned authority were available from the Scytho-Siberian groups and polities in the Minusinsk Basin and Tuva in southern Siberia (Jacobson 1993; Savinov 1989; Vainshtein 1980) and in other surrounding areas. More to the point, however, is the broad pattern evident in the emergence of authority in early civilizations around the world. Leaders find ways to legitimate control, and the most successful seem to be those with broad cultural value modified from traditional sources. In almost 
all instances, authority is sanctioned by the gods, if not the direct actions of leaders assigned godlike qualities (Trigger 2003:85).

While the emphasis in this study has been on elite representation, there is a recent focus on individuals and nonelites as a way of demarcating the influence of dominant ideologies and arenas of communication within systems of thought. One way of tracking the implementation of ideologies of power in such interactions is through patterns of material expression-that is, artifacts, architecture, and the context within which materiality operates (e.g., Minert 1985:190-191; Steinhardt 1988). It is from this perspective that ongoing archaeological research will shed light on several of the themes raised in this study. Early written sources provide evidence that continuities in systems of belief were articulated through culturally significant materialization, including architecture, sacred places, and places with cultural significance, such as the Orkhon River Valley.

Given continuities in cultural and economic practices, especially the legitimation of authority, the dynamics of the construction and maintenance of order becomes the context in which organizational coherence emerges. In particular, the construction of order is explored here because of the widely perceived ephemeral and unsustainable nature of the steppe polities. Such a critique plays into the further perception that relegates nomads-whether they are agropastoralists or not - as existing beyond the margins of the significant centers of civilization. This perspective, however, is contradicted by evidence in forms of cultural continuity, economic patterns, and the strategies used by emerging states to maintain political and organizational control of the populace. The success of the polity often hinges on the latter issue-specifically, the strategies used to bridge ethnic and linguistic diversity. There are several ways to do this, running the gamut from attempts to eliminate diversity to forms of marginal incorporation. Of the differing strategies, marginal incorporation was widely used as a technique for extracting tribute, but little else. As an approach, it produced the least integrated solution to management of diversity, but it also required the least amount of bureaucracy.

In several instances, the information needed to evaluate or expand different parts of the framework discussed here are simply not available. All sources of information have their limitations, and although early documentary sources provide a rich and diverse source, there are perspectives and research questions that can benefit from seeking new lines of evidence. Archaeological information also has its limitations; however, there is significant potential yet to be realized. In part, this is the by-product of the relatively small amount of work so far accomplished in Inner Asia, although it is also the result of theoretical orientations and methodologies. In the coming decade, approaches likely to produce the most significant contributions include (1) basic studies of subsistence practices, especially evidence for agriculture; (2) regional studies that consider site distributions and functions, such as the relationship of urban centers to surrounding regions; and (3) the study of urban centers themselves, especially evidence for craft specialization and the materialization of authority through the spatial organization of status and managerial functions. The application of these approaches to the extensive archaeological record from eastern Inner Asia will contribute to the resolution of regional questions and the analysis of emergence and continuity in authority and order. 


\section{ACKNOWLEDGMENTS}

The research on which this article is based was immeasurably assisted by Ch. Dalai, director, Institute of History, the Mongolian Academy of Sciences, and D. Tseveendorj, director of the Mongolian Institute of Archaeology. Versions of this article were significantly improved by the comments provided by several people, especially William Honeychurch and Carla Sinopoli. I also want to acknowledge the intellectual support provided by an interdisciplinary team of scholars working at the Smithsonian and George Mason University on computational social science approaches to the analysis of early states and empires. Some of the key individuals in this group are Claudio Cioffi-Revilla, Paula DePriest, William Fitzhugh, Bruno Frohlich, William Honeychurch, Sean Luke, Dawn Parker, and Max Tsvetovat. I appreciate the support provided by Sarah Kurnick and thank Matthew Gallon for his original work on the illustration. This research was partially supported by the National Science Foundation (BCS-0527471).

\section{REFERENCES CITED}

ADAMS, ROBERT M.

1988 Contexts of civilizational collapse: A Mesopotamian view, in The Collapse of Ancient States and Civilizations: 20-43, ed. N. Yoffee and G. L. Cowgill. Tucson: University of Arizona Press.

Allard, Francis, and Dimmajav Erdenebaatar

2005 Khirigsuurs, ritual and mobility in the Bronze Age of Mongolia. Antiquity 79:547-563.

Alcock, Susan E., Terence N. D'Altroy, Kathleen D. Morrison, and Carla M. Sinopoli

2001 Empires. Cambridge: Cambridge University Press.

Allsen, Thomas T.

1996 Spiritual geography and political legitimacy in the Eastern Steppe, in Ideology and the Formation of Early States: 116-135, ed. H.J.M. Claessen and J. G. Oosten. Leiden: E. J. Brill.

1997 Commodity and Exchange in the Mongol Empire: A Cultural History of Islamic Textiles. Cambridge: Cambridge University Press.

Askarov, A., V. Volkov, and N. Ser-Odjav

1999 Pastoral and nomadic tribes at the beginning of the first millennium B.C., in The Dawn of Civilization: Earliest Times to 700 B.C.: $459-472$, ed. A. H. Dansi and V. M. Masson. Vol. 1 of History of Civilizations of Central Asia. Delhi: Motilal Banarsidass Publishers.

Baines, John, AND Norman Yoffee

1998 Order, legitimacy, and wealth in ancient Egypt and Mesopotamia, in Archaic States: 199260, ed. G. M. Feinman and J. Marcus. Santa Fe: School of American Research.

2000 Order, legitimacy, and wealth: Setting the terms, in Order, Legitimacy, and Wealth in Ancient States: 13-17, ed. J. Richards and M. Van Buren. Cambridge: Cambridge University Press.

BARField, Thomas J.

1989 The Perilous Frontier: Nomadic Empires and China. Oxford: Blackwell.

2001 The shadow empires: Imperial state formation along the Chinese-Nomad frontier, in Empires: Perspectives from Archaeology and History: 10-41, ed. S. E. Alcock, T. N. D'Altroy, K. D. Morrison, and C. M. Sinopoli. Cambridge: Cambridge University Press.

BENDER, BARBARA

1990 The dynamics of nonhierarchical societies, in The Evolution of Political Systems: Sociopolitics in Small-Scale Sedentary Societies: 247-263, ed. S. Upham. Cambridge: Cambridge University Press.

Blanton, Richard E.

1998 Beyond centralization: Steps toward a theory of egalitarian behavior in archaic states, in Archaic States: 135-172, ed. G. M. Feinman and J. Marcus. Santa Fe: School of American Research Press.

Blanton, Richard E., Stephen A. Kowalewski, and Peter N. Peregrine

1996 A dual-processual theory for the evolution of Mesoamerican civilization. Current Anthropology $37(1): 1-14$. 
BOLD, BAT-OCHIR

2001 Mongolian Nomadic Society: A Reconstruction of the 'Medieval' History of Mongolia. Nordic Institute of Asian Studies, Monograph Series. Richmond, UK: Curzon Press.

Bondarenko, D. M., And A. V. Korotayev, eds.

2000 Civilizational Models of Politogenesis. Moscow: Russian Academy of Sciences, Center for Civilizational and Regional Studies.

Bourdieu, Pierre

1977 Outline of a Theory of Practice. Cambridge: Cambridge University Press.

Boyle, Katie, Colin Renfrew, and Marsha Levine, eds.

2002 Ancient Interactions: East and West in Eurasia. Cambridge: McDonald Institute for Archaeological Research.

BRONSON, BENNET

1988 The role of barbarians in the fall of states, in The Collapse of Ancient States and Civilizations: 196-218, ed. N. Yoffee and G. L. Cowgill. Tucson: University of Arizona Press.

2000 Order, legitimacy, and wealth in ancient China, in Order, Legitimacy, and Wealth in Ancient States: 120-127, ed. J. Richards and M. Van Buren. Cambridge: Cambridge University Press.

Chaliand, Gerard

2004 Nomadic Empires: From Mongolia to the Danube. New Brunswick, NJ: Transaction Publishers.

Chang, C., P. A. Tourtellotte, K. M. Baipakov, and F. P. Grigoriev

2002 The Evolution of Steppe Communities from the Bronze Age through Medieval Periods in Southeastern Kazakhstan (Zhetysu): The Kazakh-American Talgar Project 1994-2001. Sweet Briar, VA, and Almaty, Kazakhstan: Sweet Briar College, the Ministry of Education and Science of the Republic of Kazakhstan, A.Kh. Margulan Institute of Archaeology.

Chang, KwANG-CHIH

1986 The Archaeology of Ancient China. New Haven: Yale University Press.

Chavannes, ÉdouARD

1913 Les Documents Chinois Découverts par Aurel Stein dans les Sables du Turkestan Oriental. Oxford: Impr. de l'Université.

Chernykh, E. N.

1992 Ancient Metallurgy in the USSR: The Early Metal Age. Cambridge: Cambridge University Press.

1997 Kargaly: Zabytyi Mir. Moskva: Institut Arkheologii.

Chernykh, E. N., S. V. Kuz'minykh, And N. I. Merpert

2002 Metallurgiya $\mathrm{v}$ tsirkumpontiiskom areale: Ot edinstva $\mathrm{k}$ raspadu areale: Ot edinstva $\mathrm{k}$ raspadu. Rossiiskaya Arkheologiya (Russian Archaeology) 1:5-23.

Chiou-Peng, Tzehuey

1998 Western Yunnan and its steppe affinities, in Archaeology, Migration and Nomadism, Linguistics: 280-304, ed. V. H. Mair. Vol. 1 of The Bronze Age and Early Iron Age Peoples of Eastern Central Asia. Philadelphia: University of Pennsylvania Museum Publications.

Christian, David

1998 A History of Russia, Central Asia and Mongolia: Inner Eurasia from Prehistory to the Mongol Empire. Oxford: Blackwell.

Cioffi-Revilla, C.

2005 A canonical theory of origins and development of social complexity. Mathematical Sociology 29(2): 133-153.

Claessen, Henri J. M., and Jarich G. Oosten

1996 Ideology and the Formation of Early States. Leiden: E. J. Brill.

Cleaves, Francis W., ed.

1982 The Secret History of the Mongols. Cambridge: Harvard University Press.

COHEN, RONALD

1978 Introduction, in Origins of the State: The Anthropology of Political Evolution: 1-20, ed. R. Cohen and E. R. Service. Philadelphia: Institute for the Study of Human Issues. 
Cribb, Roger

1991 Nomads in Archaeology. Cambridge: Cambridge University Press.

D'Altroy, T., And T. Earle

1985 Staple finance, wealth finance, and storage in the Inca political economy. Current Anthropology 26(2): 187-206.

DAwSON, Christopher

1955 The Mongol Mission: Narratives and Letters of the Franciscan Missionaries in Mongolia and China in the Thirteenth and Fourteenth Centuries. New York: Sheed and Ward.

DeMarrais, Elizabeth, Luis J. Castillo, and Timothy Earle

1996 Ideology, materialization, and power strategies. Current Anthropology 37(1):15-31.

DE RACHEWILTZ, IGOR

1970 Some remarks on the ideological foundations of Chingis Khan's empire, in Proceedings of the Second International Congress of Mongolists: 47-56. Ulaan Baatar: BNMAU Olon Ulsyn Mongolch.

Di Cosmo, Nicola

1994 Ancient Inner Asian nomads: Their economic basis and its significance in Chinese history. Journal of Asian Studies 53:1092-1126.

1999 State formation and periodization in Inner Asian history. Journal of World History 10: $1-40$.

2002 Ancient China and Its Enemies: The Rise of Nomadic Power in East Asian History. Cambridge: Cambridge University Press.

DiRKS, NichOlas B., ED.

1992 Colonialism and Culture. Ann Arbor: University of Michigan Press.

Ehrenreich, R. M., C. L. Crumley, and J. E. Levy, eds.

1995 Heterarchy and the Analysis of Complex Society. Washington: American Anthropological Association.

Eliade, Mircea

1964 Shamanism: Archaic Techniques of Ecstasy. Princeton: Princeton University Press.

Feinman, Gary M., and Joyce Marcus, eds.

1998 Archaic States. Santa Fe: School of American Research Press.

Fitzhugh, William, Jamstranjay Bayarsaikhan, and Peter K. Marsh, eds.

2005 The Deer Stone Project: Anthropological Studies in Mongolia 2002-2004. Washington, DC: Arctic Studies Center, Smithsonian Institution.

FLANnery, Kent V.

1999 Process and agency in early state formation. Cambridge Archaeological Journal 9(1):3-21.

Frachetti, Michael

2002 Bronze Age exploitation and political dynamics of the Eastern Eurasian Steppe Zone, in Ancient Interactions: East and West in Eurasia: 87-96, ed. K. Boyle, C. Renfrew, and M. Levine. Cambridge: McDonald Institute for Archaeological Research.

2004 Bronze Age Pastoral Landscapes of Eurasia and the Nature of Social Interaction in the Mountain Steppe Zone of Eastern Kazakhstan. Ph.D. diss. University of Pennsylvania, Philadelphia.

Friedman, Jonathan, and M. Rowlands, eds.

1977 The Evolution of Social Systems. London: Duckworth.

Gailey, Christine

1985 The kindness of strangers: Transformations of kinship in precapitalist class and state formation. Culture 5(2):3-16.

GELLNER, ERNEST

1994 Foreword, in Nomads and the Outside World, 2nd ed: ix-xxv, ed. A. M. Khazanov. Madison: University of Wisconsin Press.

Golden, Peter B.

1982 Imperial ideology and the sources of unity among the pre-Činggisid nomads of western Eurasia. Archivum Eurasiae Medii Aevi 2:37-76.

1992 Introduction to the History of the Turkic Peoples: Ethnogenesis and State Formation in Medieval and Early Modern Eurasia and the Middle East. Wiesbaden: Otto Harrassowitz. 
HeISSIG, WALTHER

1980 The Religions of Mongolia. London: Routledge and Kegan Paul.

HELMS, MARY W.

1988 Ulysses' Sail: An Ethnographic Odyssey of Power, Knowledge, and Geographical Distance. Princeton: Princeton University Press.

Honeychurch, William, and Chunag Amertuvshin

2002 Pastoral production, finance, and organization of a Medieval nomadic polity in Mongolia. Paper presented at the sixty-seventh annual meeting of the Society for American Archaeology, Denver, CO.

2006 States on horseback: The rise of Inner Asian confederations and empires, in Archaeology of Asia: 255-278, ed. Miriam T. Stark. Malden, MA: Blackwell Publishing.

HulsewÉ, A.F.P.

1979 China in Central Asia, the Early Stage: 125 B.C.-A.D. 23. Leiden: Brill.

Hunt, Eva, and Robert C. Hunt

1978 Irrigation, conflict, and politics: A Mexican case, in Origins of the State: The Anthropology of Political Evolution: 69-123, ed. Ronald Cohen and Elman R. Service. Philadelphia: Institute for the Study of Human Issues.

IDshinnorov, S., D. NansalmaA, Ts. Ayush, and Ts. Ochirhuyag

2000 National Museum of Mongolian History. Ulaan Baatar: Decom Studio.

IRONS, WILLIAM

1979 Political stratification among pastoral nomads, in Pastoral Production and Society: 361-374, ed. L’Équipe Écologie et Anthropologie des Sociétés Pastorales. Cambridge: Cambridge University Press.

IsHJAMTS, $\mathrm{N}$.

1994 Nomads in eastern Central Asia, in The Development of Sedentary and Nomadic Civilizations: 700 B.C. to A.D. 250: 151-169, ed. J. Harmatta, B. N. Puri, and G. F. Etemadi. Vol. 2 of History of Civilizations of Central Asia. Paris: UNESCO Publishing.

JACOBSON, ESTHER

1993 The Deer Goddess of Ancient Siberia: A Study in the Ecology of Belief. Leiden: E. J. Brill.

Jagchid, Sechin, and VAn J. Symons

1989 Peace, War, and Trade along the Great Wall. Bloomington: Indiana University Press.

Johnson, Allen W., and Timothy Earle

1987 The Evolution of Human Societies: From Foraging Group to Agrarian State. Stanford: Stanford University Press.

Jones-Bley, K., And D. G. Zdanovich, eds.

2002 Complex Societies of Central Eurasia from the 3rd to the 1st Millennium B.C.: Regional Specifics in Light of Global Models. Journal of Indo-European Studies Monograph Series 46. Washington, DC: Institute for the Study of Man.

Joyce, Rosemary A.

2000 High culture, Mesoamerican civilization, and the Classic Maya tradition, in Order, Legitimacy, and Wealth in Ancient States: 64-76, ed. J. Richards and M. Van Buren. Cambridge: Cambridge University Press.

JuWAyni, 'Ata-Malik

1912- Ta'rikh-i Jahan-Gusha. Ed. Mirza Muhammad Qazvini. E.J.W. Gibb Memorial Series 16.

1937 London: Luzac.

1958 The History of the World Conqueror. Trans. John A. Boyle. Manchester: Manchester University Press.

Khazanov, Anatoly M.

1981 The early state among the Scythians, in The Early State: 425-440, ed. H.J.M. Claessen and P. Skalník. The Hague: Mouton.

1993 Muhammad and Jenghiz Khan compared. Comparative Studies in Society and History 35(3) : 461-479.

1994 Nomads and the Outside World, 2nd ed. Madison: University of Wisconsin Press.

2001 Nomads in the history of the sedentary world, in Nomads in the Sedentary World: 1-23, ed. A. M. Khazanov and W. André. Richmond, UK: Curzon. 
KRADER, LAWRENCE

1978 The origin of the state among the nomads of Asia, in The Early State: 93-107, ed. H.J.M. Claessen and P. Skalník. The Hague: Mouton.

Kradin, Nikolay N.

2002 Nomadism, evolution and world-systems: Pastoral societies in theories of historical development. Journal of World-Systems Research 8(3): 368-388.

2005 Social and economic structure of the Xiongnu of the Trans-Baikal region. Archaeology, Ethnology and Anthropology of Eurasia 21(1):79-86.

KürSAT-AhLERS, ELÇIN

1994 Zur frühen Staatenbildung von Steppenvölkern. Berlin: Duncker and Humblot.

1996 The role and contents of ideology in the early nomadic empires of the Eurasian steppes, in Ideology and the Formation of Early States: 136-152, ed. H.J.M. Claessen and J. G. Oosten. Leiden: E. J. Brill.

Kuzmina, E. E.

1998 Cultural connections of the Tarim Basin people and pastoralists of the Asian steppes in the Bronze Age, in Archaeology, Migration and Nomadism, Linguistics: 63-98, ed. V. H. Mair. Vol. 1 of The Bronze Age and Early Iron Age Peoples of Eastern Central Asia. Philadelphia: University of Pennsylvania Museum Publications.

2001 Andronovo, in Encyclopedia of Prehistory, Europe, vol. 4:1-21, ed. P. N. Peregrine and M. Ember. New York: Kluwer Academic/Plenum Publishers.

LATTIMORE, OWEN

1940 Inner Asian Frontiers of China. American Geographical Society Research Series 21. New York: American Geographical Society.

1976 Herders, farmers, urban culture, in Pastoral Production and Society: Proceedings of the International Meeting on Nomadic Pastoralism: 479-490, ed. L’Équipe Écologie et Anthropologie des Sociétés Pastorales. Cambridge: Cambridge University Press.

LeE, Yun KueN

2002 Building the chronology of early Chinese history. Asian Perspectives 41(1):15-42.

LEHMAN, E. H.

1969 Toward a macrosociology of power. American Sociological Review 34 : 453-465.

LI, SHuicheng

2002 The interaction between northwest China and Central Asia during the second millennium B.c.: An archaeological perspective, in Ancient Interactions: East and West in Eurasia: 171-182, ed. K. Boyle, C. Renfrew, and M. Levine. Cambridge: McDonald Institute for Archaeological Research.

LI, ZONGTONG

1973 Qunqiu Zuozhuan Jinju Jinyi (Annotated edition of the Qunqiu Zuozhuan). Taipei: Shangwu Yinshuguan.

LINDUFF, K. M., ED.

2004 Metallurgy in Ancient Eastern Eurasia from the Urals to the Yellow River. Lewiston, NY: Edwin Mellen Press.

LIU, LI

1996 Settlement patterns, chiefdom variability, and the development of early states in North China. Journal of Anthropological Archaeology 15 :237-288.

Mackerras, Colin

1972 The Uighur Empire According to the T'ang Dynastic Histories. Canberra: Australian National University.

Mei, Jianjun, and Colin Shell

2002 The Iron Age cultures in Xinjiang and their steppe connections, in Ancient Interactions: East and West in Eurasia: 213-234, ed. K. Boyle, C. Renfrew, and M. Levine. Cambridge: McDonald Institute for Archaeological Research.

Miller, Daniel, Michael Rowlands, and Christopher Tilley

1989 Domination and Resistance: One World Archaeology. Boston: Unwin Hyman.

MineRT, L. K.

1985 Drevneishie pamiatniki Mongol'skogo monumental'nogo zodchestva, in Drevnie kul'tury Mongolii: 184-209, ed. R. S. Vasil'evskii. Novosibirsk: Izdatel'stvo Nauka. 
MiNORSKY, V.

1947 Tamin ibn Bahr's journey to the Uyghurs. Bulletin of the School of Oriental and African Studies $12(1): 275-305$.

PARKER, EDWARD H.

1894- The Turko-Scythian tribes. China Review $21: 100-119,129-137,253-267,291-301$.

1895

1900- The early Turks. China Review 25:1-270.

1901

PENG, Ke

1998 The Andronovo bronze artifacts discovered in Toquztara County in Ili, Xinjiang, in Genetics and Physical Anthropology, Metallurgy, Textiles, Geography and Climatology, History, and Mythology and Ethnology: 573-580, ed. V. H. Mair. Vol. 2 of The Bronze Age and Early Iron Age Peoples of Eastern Central Asia. Philadelphia: University of Pennsylvania Museum Publications.

Pletneva, S. A.

1982 Kochevniki Srednevekovia. Moscow: Nauka.

Potapov, L. P.

1955 Materialy Obedinennoi Nauchnoi Sessii, Posviashchennoi Istorii Srednei Azii $i$ Kazakhstana $v$ Dooktiabrskii Period. Tashkent: Izdatelstvo Akademii Nauk Uzbekskoi SSR.

Price, Barbara J.

1978 Secondary state formation: An explanatory model, in Origins of the State: The Anthropology of Political Evolution: 161-186, ed. R. Cohen and E. R. Service. Philadelphia: Institute for the Study of Human Issues.

PRITSAK, OMELJAN

1981 The Origin of Rus': Old Scandinavian Sources Other Than the Sagas. Cambridge, MA: Harvard University Press.

Richards, JANET, AND MARy VAN Buren, eds.

2000 Order, Legitimacy, and Wealth in Ancient States. Cambridge: Cambridge University Press.

Richards, JANET, AND TERRY WILFONG, EDS.

1995 Preserving Eternity: Modern Goals, Ancient Intentions. Ann Arbor: Kelsey Museum of Archaeology.

Rogers, J. DANIEI

2005 Archaeology and the interpretation of colonial encounters, in The Archaeology of Colonial Encounters: Comparative Perspectives: 331-354, ed. Gil Stein. Santa Fe: School of American Research.

Rogers, J. Daniel, Erdenebat Ulambayar, and Mathew Gallon

2005 Urban centres and the emergence of empires in eastern Inner Asia. Antiquity 79:801818.

Rosen, Arlene M., Claudia Chang, and Fedor P. Grigoriev

2000 Palaeoenvironments and economy of Iron Age Saka-Wusun agro-pastoralists in southeastern Kazakhstan. Antiquity 74:611-623.

Sahlins, Marshall

1981 Historical Metaphors and Mythical Realities: Structure in the Early History of the Sandwich Islands Kingdom. Ann Arbor: Association for Social Anthropology in Oceania.

SAvinov, DMitri

1989 The Sayano-Altaic centre of early Medieval cultures. Antiquity 63:814-826.

Schortman, Edward M., and Patricia A. Urban

1992 The place of interaction studies in archaeological thought, in Resources, Power, and Interregional Interaction: 3-21, ed. Edward M. Schortman and Patricia A. Urban. New York: Plenum.

Shen, Chen

2003 Compromises and conflicts: Production and commerce in the royal cities of Eastern Zhou, China, in The Social Construction of Ancient Cities: 290-310, ed. M. L. Smith. Washington, DC: Smithsonian Institution Press. 
Sinopoli, Carla M.

2001 Empires, in Archaeology at the Millennium: A Sourcebook: 439-471, ed. Gary M. Feinman and T. Douglas Price. New York: Kluwer Academic/Plenum Publishers.

SPENCER, C. S.

1994 Factional ascendance, dimensions of leadership, and the development of centralized authority, in Factional Competition and Political Development in the New World: 31-43, ed. E. M. Brumfiel and J. W. Fox. Cambridge: Cambridge University Press.

Stein, Gil J.

1998 Heterogeneity, power, and political economy: Some current research issues in the archaeology of Old World complex societies. Journal of Archaeological Research 6:1-44.

Steinhardt, Nancy S.

1988 Imperial architecture along the Mongolian Road to Dadu. Ars Orientalis 18:59-93.

SU, T'IEN-CHÜEH

1967 Yüan Wen-lei. Taipei: Shih-chieh shu-chü.

Terent'ev-Katanskit, A. P.

1993 Materialnaia Kul'tura Si Sia. Moscow: Vostochnaia Literatura.

Trigger, Bruce G.

2003 Understanding Early Civilizations: A Comparative Study. Cambridge: Cambridge University Press.

VAinshtein, S. I.

1980 Nomads of South Siberia: The Pastoral Economies of Tuva. Cambridge: Cambridge University Press.

VAN Buren, Mary, and Janet Richards

2000 Introduction: Ideology, wealth, and the comparative study of "civilizations," in Order, Legitimacy, and Wealth in Ancient States: 3-13, ed. Janet Richards and Mary Van Buren. Cambridge: Cambridge University Press.

Watson, Burton, Trans.

1961 The Age of Emperor Wu 140 to circa 100 B.C. Vol. 2 of Records of the Grant Historian of China, translated from the Shih Chi of Ssu-ma Ch'ien. New York: Columbia University Press.

WEISSLEDER, WOLFGANG

1978 Introduction, in The Nomadic Alternative: Modes and Models of Interaction in the AfricanAsian Deserts and Steppes: xiii-xviii, ed. Wolfgang Weissleder. The Hague: Mouton.

WRIGHT, HenRY T.

1977 Recent research on the origin of the state. Annual Review of Anthropology 6:379-397.

Yamada, NobuO

1982 Formation of the Hsiung-Nu nomadic state. Acta Orientalia Academiae Scientiarum Hungaricae $36: 575-582$.

YING-SHIH, Yü

1967 Trade and Expansion in Han China: A Study in the Structure of Sino-Barbarian Economic Relations. Berkeley: University of California Press.

Yoffee, Norman

2005 Myths of the Archaic State: Evolution of the Earliest Cities, States, and Civilizations. Cambridge: Cambridge University Press.

Yoffee, Norman, and George L. Cowgill, eds.

1988 The Collapse of Ancient States and Civilizations. Tucson: University of Arizona Press.

\begin{abstract}
Three key themes consistently play a role in the study of early state formation in eastern Inner Asia. First, scholars have frequently argued that China exerted a disproportionately strong influence on steppe polities, serving as a source of goods and ideas for neighboring pastoralist societies. Although Chinese states did very signifi-
\end{abstract}


cantly influence steppe polities, interactions were complex and highly variable. Rather than being dominated by Chinese states, exchanges and interactions were often on a level of parity or were under the control of the steppe polities. It is frequently argued that the fragility of the pastoralist economy required steppe polities to acquire agricultural products, which in turn fostered a dependency on agricultural societies in the south. New evidence, however, suggests that the traditional distinction between pastoralist and agriculturalist economies may be insufficient to characterize the complex sets of interactions. Second, steppe polities are often described as short-lived entities that succeeded each other in rapid succession. This description deemphasizes the economic and cultural continuity that transcended the rise and fall of individual political entities. The third theme concerns the construction and maintenance of order. How, in other words, did rulers legitimate their power and maintain political and organizational control of populations and territories? Most interpretations argue that steppe polities looked to neighboring states for the cultural knowledge that allowed them to create and maintain order. That knowledge, however, came from multiple sources-especially the internal traditions that linked successive steppe polities. Keywords: state formation, empires, Inner Asia, social theory, power relations. 